\title{
Growth and Yield of Tomato Grown Under Organic and Inorganic Nutrient Management
}

Priyanshu Singh ${ }^{1}$, Diwaker Singh ${ }^{1}$, Anand Kumar Singh², B. K. Singh ${ }^{2}$ and Tejbal $\operatorname{Singh}^{3} *$

${ }^{1}$ Department of Horticulture, Faculty of Agriculture, Udai Pratap Autonomous College, Varanasi - 221002 (U.P.), India

${ }^{2}$ Department of Horticulture, ${ }^{3}$ Department of Agronomy, Institute of Agriculture Science, Banaras Hindu University, Varanasi- 221005

*Corresponding author

\section{A B S T R A C T}

\section{Ke y w o r ds \\ Organic manures, FYM, PM, VC, \\ Chemical fertilizer, Nutrient management, Fruit yield}

\section{Article Info}

Accepted:

05 February 2020

Available Online:

10 March 2020
Sustainable agricultural development and crop yield maximization is the major objective of present Indian agriculture, which can be achieved through restoration and scientific management of land productivity. Under such circumstances, organic nutrient supply system plays key role as they not only supply macronutrients but also supply micronutrients as well as certain hormones and metabolites. However, nutrient management plays an important role in growth and yield of tomato. Viewing these facts, a field experiment was conducted during the winter season of 2016- 2017 to analyze the Growth and Yield of Tomato Grown Under Organic and Inorganic Nutrient Management. The organic sources of fertilizer were farm yard manure (FYM), poultry manure (PM), vermicompost (VC) with three levels of each and one chemical fertilizer dose applied as 100\% RDF of NPK. The chemical fertilizer (CF) applied at recommended dose of 180: 60: $60 \mathrm{~kg} \mathrm{ha}{ }^{-1}$ of $\mathrm{N}: \mathrm{P}_{2} \mathrm{O}_{5}: \mathrm{K}_{2} \mathrm{O}$ for the tomato. The results revealed that application of $10 \mathrm{t}$ poultry manure $\mathrm{ha}^{-1}$ recorded maximum growth attributes, yield parameters and fruit yield (584.69 $\mathrm{q} \mathrm{ha}^{-1}$ ), which was significantly superior to its own lower levels poultry manure and rest of two organic manure's levels as well as inorganically nurtured tomato crop i.e. $100 \%$ RDF of NPK through chemical fertilizer. However, higher levels of each organic manure found significantly higher for all the growth and yield parameters as well as fruit yield.

\section{Introduction}

As overpopulation takes place in India, producers find themselves under pressure to meet augmented demand for food with limited resource constraints on production and distribution channels. To cope with increasing demand of crop yields, producers cut corners and attempt to inflate their production line. This jeopardizes the quality of the crop, thus hampering food standards. Most food sectors are under the risk of falling standards, linked to agriculture sectors like food grains, fruits and vegetables, as well as byproducts. 
Moreover, as population enlarges, there is stress on factors of production viz. loss of agricultural land to urbanization, groundwater depletion, potential flooding, etc. The greatest risk to food quality posed by a rising population is declining production standards as producers confined to short cuts for higher yields. Short term actions to increase the production levels can degrade food quality standards and harm the long-term production outlook, exasperating problems like soil degradation. These emerging problems can be overcome by adopting sustainable production system. Sustainable agricultural development and crop yield maximization is the major objective of present Indian agriculture, which can be achieved through restoration and scientific management of land productivity. Under the goal of yield maximization, intensive cropping is an appropriate measure and amount of nutrients are indispensable. In conventional practice, improved cropping systems involving high-value crops depend on the use of inorganic fertilizers because of the immediate availability of nutrients. In the one hand, chemical fertilizers can nourish plants, but in the other hand, they also put at risk the environment through nitrate and other chemicals as well as heavy metal pollution. These have adverse effects on fragile ecosystems with elimination of beneficial soil organisms and a deterioration in physicochemical properties of the soil ultimately deteriorate the soil health (Mahajan et al., 2008 and Savci, 2012). Indiscriminate and irrational use of such chemical fertilizers leads to yield instability and also poses threat to the soil health, particularly due to micronutrient deficiency and fertilizer-related environmental pollution (Prasad and Power 1995, Savci, 2012). Moreover, the produce so obtained may be of questionable quality and acceptability at market. A need of growing consciousness of such overdependence on synthetic chemicals and the associated degradation in product and environmental quality have led to the emergence of a system known as 'organic farming'. It provides options for the restoration and augmentation of soil fertility and improvement of crop yield and quality in an intensive cropping system.

Whereon, tomato crop occupies very important place. It plays a very vital role in human diet and is a good source of vitamins and minerals (Bhowmik et al., 2012). The fruits are eaten either raw or cooked and can be processed into soup, juice, sauce, ketchup, puree, paste and powder as well as serve as an ingredient in stews and vegetable salads. Tomato is a savory, typically red, edible fruit and is an excellent source of valuable nutrients (Singh et al., 2014) and secondary metabolites that are important for human health, namely folate, potassium, vitamin A, $\mathrm{B}$, and $\mathrm{E}$ (Vallejo et al., 2002) essential amino acids, sugars, dietary fibres (Kalbani et al., 2016), flavonoids, chlorophyll, $\beta$-carotene and antioxidants such as lycopene and vitamin $\mathrm{C}$ which are essential for human health (Kallo, 1993; Clinton, 1998; Kanr et al., 2002). It also contains much iron and phosphorus (Kalbani et al., 2016) Lycopene, is the most important antioxidant has been linked with reduced risk of prostrate and various other forms of cancer as well as heart diseases (Barber and Barber, 2002). Tomato requires heavy fertilization $(120-150 \mathrm{~kg} \mathrm{~N}, 60-80 \mathrm{~kg}$ $\mathrm{P}_{2} \mathrm{O}_{5}$ and $80 \mathrm{~kg} \mathrm{~K}_{2} \mathrm{O} \mathrm{ha}^{-1}$ ) for its optimum production. Application of these nutrients through chemical fertilizers is not much affordable and their use is not eco-friendly as well as factor productivity also declining day by day.

Therefore, there is an urgent need to utilize other sources of plant nutrients for sustainable and safe tomato production. The answer lies in the use of different form of organic manures which have a potential to provide primary, secondary and micronutrients besides building a strong organic matter base 
resulting in improvement of soil structure and sustainable vegetable production devoid of most of the harmful residues and the vegetables produced are preferred for their flavor, taste, luster, nutritive value and being sold at premium prices. Variations in tomato growth and yield might be due to differences in nutrient management under similar as well as varying agro-climatic conditions. However, limited research information is available on tomato growth and yield under varying nutrient management systems in the Varanasi region of North India. The objective of this study was a comparative assessment of the effect of organic and chemical fertilizer sources on tomato growth and yield in an Indo-Gangetic alluvial soil of North India.

\section{Materials and Methods}

\section{Description of the study site}

Indo-Gangetic basin is the largest alluvial tract in the world formed as a consequence of collision between Indian and Asian plates. Varanasi region of eastern Uttar Pradesh is a part of north Indo-Gangetic basin where experiment was carried out entitled "Growth and Yield of Tomato Grown Under Organic and Inorganic Nutrient Management" at experimental farm of Udai Pratap Autonomous College, Bhojubeer-Varanasi situated at $82^{\circ} 58^{\prime} 20^{\prime \prime} \mathrm{E}$ longitude and $25^{\circ}$ 21 ' 13 " $\mathrm{N}$ latitude of $80.71 \mathrm{~m}$ above mean sea level.

Meteorological data of the experimental area represented in Figure 1 indicates that crop planting season was winter and during cropping period the area has mean minimum and maximum temperatures were $13.4^{\circ} \mathrm{C}$ and $27.43^{\circ} \mathrm{C}$ during the growing season.

The soil is sandy loam with sand, silt and clay proportionated to $48.15 \%, 21.34 \%$ and $30.51 \%$ respectively. $\mathrm{pH}$ is nearly neutral $i$. $e$.
6.87 of $15 \mathrm{~cm}$ soil horizon contains $212.56 \mathrm{~kg}$ $\mathrm{ha}^{-1}$ available nitrogen, $37.32 \mathrm{~kg} \mathrm{ha}^{-1}$ available phosphorus, $210.05 \mathrm{~kg} \mathrm{ha}$ available potassium, $0.4 \%$ organic carbon, and 0.35 $\mathrm{dsm}^{-1}$ of EC at $25^{0} \mathrm{C}$.

\section{Materials used for the experiment}

\section{Treatment materials}

Treatments has been grouped into two category as organic and inorganic nutrient supply system which consisted of three nutrient sources with three levels of each viz. FYM (10, 20, and 30t ha $\left.{ }^{-1}\right)$, poultry manure (PM: 5.0, 7.5 and $10 \mathrm{t} \mathrm{ha}^{-1}$ ), Vermicompost (VC: $2.5,5.0$, and 7.5t ha ${ }^{-1}$ ) and another one inorganic source as recommended dose of $\mathrm{N}$, $\mathrm{P}_{2} \mathrm{O}_{5}$ and $\mathrm{K}_{2} \mathrm{O}$ (180: 60: 60) for hybrid tomato was applied through inorganic fertilizers. Different organic manures were purchased and samples were brought to laboratory, shade dried followed by nutrient composition was analyzed with standard protocols given by different scientists and the values are enlisted in Table 1.

In inorganic source, recommended dose of $\mathrm{N}$, $\mathrm{P}$, Kis supplied through chemical fertilizer were Urea $(46 \% \mathrm{~N})$, Diammonium phosphate (DAP: $46 \% \quad \mathrm{P}_{2} \mathrm{O}_{5}$ and $18 \% \mathrm{~N}$ ), and $\mathrm{MOP}$ $\left(60 \% \mathrm{~K}_{2} \mathrm{O}\right)$.

\section{Planting material}

Seedlings of Kashi-Vishesh $\left(\mathrm{F}_{1}\right.$ hybrid : $\mathrm{H}-$ 86)characterized as resistant to Tomato leaf curl virus (ToLCV), developed from IIVR, Varanasi by using Lycopersicum hirsutum $\mathrm{f}$. glabratum B'6013' x Sel 7 as donor parent following backcross pedigree selection method, plants determinate, dark green, fruits are red with spherical in shape, size medium to large, average fruit weight $80 \mathrm{~g}$ with yield potential of $400-450 \mathrm{qha}^{-1}$. 


\section{Experimental design and procedure}

The experiment was conducted during the main cropping season of tomato i.e. winter season from mid-September to mid-March. This was laid out in a randomized complete block design and replicated three times as per treatment with the plot sizes of gross and net were $2.25 \mathrm{~m} \times 4.2 \mathrm{~m}$ and $1.8 \mathrm{~m} \times 3.6 \mathrm{~m}$, respectively. Shade dried FYM,PM, and VC were assembled followed by they were applied on dry weight basis on a month prior to planting and thoroughly mixed with the soil. While, the plots with inorganic treatment were fertilized by chemical fertilizers i.e. Urea, Diammonium phosphate, and MOP as half of nitrogen and potash and full dose of phosphorus applied at the time of bed preparation. The remainder was applied when flowering initiated in plants. Transplanting of nursery seedling was done at $8^{\text {th }}$ November, 2016 followed by one light irrigation at a same time and second one at 4 Day after transplanting (DAT) by water cane to withstand the crop. Afterwards, five full irrigation were sufficient to bring tomato crop at final eighth picking stage. Two manual hand weeding, first at 35 DAT and second weeding along with earthing up done at 60 DAT to manage weeds in crop, followed by staking operation carried out. Plant protection practices were carried out as per requirement and harvesting was done by 8manualpicking as first picking starts at 80 DAT and subsequently done at 5 days intervals.

\section{Data collection and measurements}

Data regarding the growth parameters were collected at several time interval viz. 30, 60, 90 DAT of which 60 and 90 DAT data has been used to deliver my research in this research paper. While, yield was calculated by adding all the fruit weights as per treatments obtained during different pickings. Thereafter, summarized data were analyzed by adopting appropriate Model "Analysis of variance" as per procedure described by Panse and Sukhatme (1967). Critical difference (CD) for the treatments was calculated in order to compare the treatments at $1 \%$ and $5 \%$ level of significance.

\section{Results and Discussion}

\section{Effect on growth attributes}

Among the different levels of organic manures and recommended dose of fertilizer (RDF) of inorganic fertilizer, the treatment receiving $10 \mathrm{t} \mathrm{ha}^{-1}$ of poultry manure showed the highest growth attributes at both the stages viz. 60 and 90 DAT, similar result has been found by Geetharani and Parthiban (2014).

Although, higher doses of organic manures significantly recorded higher growth attributes at all the stages of cropping season as compared to lower levels of organic manures. In general, application of poultry manure recorded taller plants as compared to FYM or vermicompost. The plant height under control (inorganic system) was significantly comparable to those under FYM @ 20.0 and $30.0 \mathrm{t} \mathrm{ha}^{-1}$, poultry manure @ 7.5 and $10 \mathrm{t} \mathrm{ha}^{-1}$ as well as vermicompost @ $7.5 \mathrm{t}$ ha $^{-1}$ at 60 DAT while, at 90DAT only treatment receiving $10 \mathrm{t} \mathrm{ha}^{-1}$ of poultry manure significantly recorded higher plant height than RDF of inorganic fertilizer. The higher number of green leaves was significantly recorded with higher levels of organic manure than lower levels of manure under organic nutrient supply system.

Under organic and inorganic system, different organic manures at different levels showed significantly higher green leaf counts than recommended dose of inorganic fertilizer except FYM @ 10t ha ${ }^{-1}$ and VC @ 2.5 and $5.0 \mathrm{tha}^{-1}$ at 60 DAT and FYM @ $10 \mathrm{t} \mathrm{ha}^{-1}$ and all levels of vermicompost at 90 DAT as they failed to touch the level of significance. 
A perusal of the data indicates that there was a significant response to different organic manures as well as their doses to leaf sizes at all the growth stages viz. 60 and 90 days after transplanting. At 60 days stage, the smallest leaves (leaf length x leaf width: $20.19 \mathrm{~cm} \mathrm{x}$ $12.69 \mathrm{~cm})$ were observed under lowest dose of (vermicompost @2.5 t ha ${ }^{-1}$ ). However, it was at par to FYM @ $10.0 \mathrm{t} \mathrm{ha}^{-1}$. At this stage, the leaf sizeswas found to be maximum $(22.69 \mathrm{~cm} \times 16.99 \mathrm{~cm})$ under poultry manure source @ 10.0 t ha ${ }^{-1}$ which was highly significant to all other treatments. With the advancement of the growth stage i.e. 90 days, the leaf size increased considerably in all the treatments. However, the growth pattern at this stage was more or less similar to that of 60 days after planting. The leaf size was maximum $(23.39 \mathrm{~cm} \mathrm{x} 17.29 \mathrm{~cm})$ under poultry manure applied @ 10.0 t ha ${ }^{-1}$ and minimum $(20.39 \mathrm{~cm}$ x $14.09 \mathrm{~cm})$ under lowest dose of vermicompost@ 2.5 tha $^{-1}$. Under organic and inorganic system, nutrient supplied to tomato crop through poultry manure@7.5 and 10.0 t ha $^{-1}$ abled to create significant differences to RDF of inorganic fertilizer at 60 DAT while, along with poultry manure@ @.5, $10.0 \mathrm{t} \mathrm{ha}^{-1}$ and FYM @ $30 \mathrm{t}$ ha $^{-1}$ at 90 DAT showed significantly higher leaf sizes than RDF of inorganic fertilizer.

The maximum number of nodes (12.19) at 60 DAT was found with the application of poultry manure @ $10.0 \mathrm{t} \mathrm{ha}^{-1}$ which, was significantly superior to all over organic as well as inorganic nutrient system. The minimum number of nodes $(7.19 \mathrm{~cm})$ was recorded under treatment receiving vermicompost@2.5 t ha ${ }^{-1}$. At 90 days of planting, different treatments resulted into a conspicuous and significant increase in number of nodes in tomato plants. However, the pattern of variation among different nutrient sources was almost similar to that of60 days after planting.
Further, number of branches in tomato plants was significantly influenced by different organic and inorganic treatments at both the growth stages. At 60 days after planting, the number of branches varied from a minimum of 10.39 under lowest level of vermicompost i.e. @ $2.5 \mathrm{t} \mathrm{ha}^{-1}$ to a maximum of 12.89 under highest level of poultry manures i.e. @ $10 \mathrm{t}$ $\mathrm{ha}^{-1}$. The number of branches under inorganic nutrient supply system (control) was significantly lower to that under FYM @ 30.0 $\mathrm{t} \mathrm{ha}^{-1}$ and poultry manure @ 7.5 and $10 \mathrm{t} \mathrm{ha}^{-1}$ while, nutrient supplied to crop by FYM@10 and $20 \mathrm{t} \mathrm{ha}^{-1}$ and all the vermicompost manure levels failed to touch the level of significance. With the advancement in crop growth stage viz. 90DAT, the number of branches in tomato increased significantly. However, the growth pattern remained almost similar to that at 60 days of planting. At 90 days growth stage, the number of branches ranged from a minimum of 12.29 under vermicompost @ $2.5 \mathrm{t} \mathrm{ha}^{-1}$ to a maximum of 14.29 under poultry manure @ 10.0 t ha $^{-1}$.

Regarding mean stem diameter at 60 and 90DAT, different nutrient sources were significantly able to create variable differences. Application of 10 tha $^{-1}$ poultry manure recorded maximum stem diameter $(0.91 \mathrm{~cm})$ at 60 DAT, which is significantly higher to lower levels of poultry manure as well as significantly superior over other nutrient sources. The minimum stem diameter $(0.63 \mathrm{~cm})$ was recorded with lowest level of vermicompost @ $2.5 \mathrm{t} \mathrm{ha}^{-1}$. Under organic and inorganic nutrient supply system, organic nutrient sources were able to create significant differences in relation to mean stem diameter than inorganic nutrient supply system i.e. $100 \%$ RD of NPK through inorganic fertilizer (IF) (control).

In general, application of poultry manure resulted superior growth attributes as compared to FYM, vermicompost and 
inorganic fertilizer. The higher growth rate in terms of plant height, green leaf count, leaf sizes, number of nodes and branches and mean stem diameter were recorded under poultry manure may be attributed due to higher supply and availability of plant nutrient in the root zone of the tomato plants and also for longer period. Poultry manure is good source of both macro nutrients $(\mathrm{N}, \mathrm{P}, \mathrm{K}$, $\mathrm{Ca}, \mathrm{Mg}, \mathrm{S})$ and micronutrients $(\mathrm{Cu}, \mathrm{Fe}, \mathrm{Mn}$, B) which has been already mentioned in earlier table 1, and can increase soil carbon and $\mathrm{N}$ content, soil porosity and enhance soil microbial activity also noticed by Ghosh et al., (2004). This indicates the superiority of poultry manure over other two other organic manures are due to higher macro as well as micro nutrients supply to tomato crop, also reported by Acharya and Kumar (2018). Similar finding in relation to organic manures have also been observed by Sumawat et al., (2001) and Naidu et al., (2000). The effects of manures on tomato plant growth characters was in the order of poultry manure > FYM>vermicompost.

In term of nutrient supply system viz. organic and inorganic, organic sources showed pronounced effect on growth attributes than inorganic nutrient supply system is mainly due to higher nutrient profile as well as presence of growth promoting hormones. Covering these facts, organic manures added higher amount of organic matter to soil which usually responsible for microbial activity enhancement (Sreenivasa et al., 2010). These leads to nutrient mineralization and supply to plant as well improvement in physicochemical properties of soil as using organic manure improves soil texture and help plant to have a good root proliferation, which leads to improvement in plant growth (Browaldh et al., 1992). The results obtained concur with earlier findings reported by Taiwo et al., (2007).

\section{Effect on yield}

Data pertaining to tomato yield as well as yield parameters influenced by various organic manures and inorganic fertilizer is presented in Table 4. The results in respect of yield parameters i.e. average fruit weight $(80.10 \mathrm{~g})$, fruit number $\left(20.79\right.$ plant $\left.^{-1}\right)$, fruit yield $\left(1.67 \mathrm{kgplant}^{-1}\right)$ as well as highest value for fruit yield (584.69 $\mathrm{q} \mathrm{ha}^{-1}$ ) were recorded under treatment receiving poultry manure @ 10 t.ha ${ }^{-1}$. Supplying of poultry manure @ $10 \mathrm{t}$. $\mathrm{ha}^{-1}$ recorded $46.18 \%$ higher fruit yield $\mathrm{q} \mathrm{ha}^{-1}$ than control i.e. $100 \%$ RD of NPK through IF $\left(399.99 \mathrm{q} \mathrm{ha}^{-1}\right)$. Among the organic treatments, successively increase in levels of poultry manure, FYM and vermicompost showed significant $(p>0.05)$ increase in average fruit weight, fruit numbers and fruit yield per plant as well as fruit yield per hectare. Higher levels of organic manures recorded higher value than the lower levels of organic manures. Among the organic manures, application of $10 \mathrm{t}$ poultry manure $\mathrm{ha}^{-1}$ recorded maximum average fruit weight $(80.10 \mathrm{~g})$, fruit numbers (20.79 plant $\left.^{-1}\right)$ and fruit yield $\left(1.67 \mathrm{~kg} \mathrm{plant}^{-1}\right)$ as well as fruit yield $\left(584.69 \mathrm{q} \mathrm{ha}^{-1}\right)$, which was significantly superior to own lower levels of poultry manure as well as each levels of other organic manures and also superior to inorganic nutrient management viz. $100 \%$ RD of inorganic fertilizer.

In terms of organic and inorganic nutrient supply system for tomato, organic manures namely FYM (@30 t ha ${ }^{-1}$ ) and poultry manure (@7.5 and $10 \mathrm{t} \mathrm{ha}^{-1}$ ) have recorded significantly superior average fruit weight, fruit numbers and fruit yield per plant as well as fruit yield per hectare to inorganic fertilizer. Wherever, vermicompost recorded statistically at par performance to inorganic fertilizer, which might be due to lower doses of vermicompost in comparison to other organic manures. The weight of fruit, fruit 
number and fruit yield per plant were directly influenced by the enhanced vegetative growth on the plants viz. significant increase in height, number of branches, number of green leaves and size (length and width) of leaves as influenced by organic treatments. One of the reasons might be more accumulation of carbohydrates due to enhanced nutrition resulting into increased weight of fruit, which is the storage organ. These results are in agreement with those reported by Singh et al., (1997) for onion crop and in tomato by Adekiya et al., (2009).

Table.1 Nutrient composition of organic manures used in experiment

\begin{tabular}{|l|l|l|l|l|l|l|l|l|l|l|l|}
\hline $\begin{array}{l}\text { Organic } \\
\text { Manure }\end{array}$ & $\mathrm{pH}$ & $\begin{array}{l}\mathrm{N} \\
(\%)\end{array}$ & $\begin{array}{l}\mathrm{P} \\
(\%)\end{array}$ & $\begin{array}{l}\mathrm{K} \\
(\%)\end{array}$ & $\begin{array}{l}\mathrm{Ca} \\
(\%)\end{array}$ & $\begin{array}{l}\mathrm{Mg} \\
(\%)\end{array}$ & $\begin{array}{l}\mathrm{S} \\
(\%)\end{array}$ & $\begin{array}{l}\mathrm{Fe}(\mathrm{mg} \\
\left.\mathrm{kg}^{-1}\right)\end{array}$ & $\begin{array}{l}\mathrm{Mn}(\mathrm{mg} \\
\mathrm{kg}^{-1}\end{array}$ & $\begin{array}{l}\mathrm{Zn} \\
(\mathrm{mg} \\
\left.\mathrm{kg}^{-1}\right)\end{array}$ & $\begin{array}{l}\mathrm{B} \\
\left(\mathrm{mg}^{-1}\right.\end{array}$ \\
\hline FYM & 6.90 & 0.61 & 0.28 & 0.57 & 0.48 & 0.18 & 0.22 & 1320.0 & 70.0 & 40.0 & 35 \\
\hline PM & 7.48 & 1.82 & 1.55 & 1.57 & 1.1 & 0.88 & 0.70 & 2080 & 400.0 & 500.0 & 109 \\
\hline VC & 7.21 & 2.23 & 0.77 & 1.02 & 0.85 & 0.42 & 0.58 & 4400 & 180 & 280 & 33.7 \\
\hline
\end{tabular}

Table.2 Effect of organic manure on plant height $(\mathrm{cm})$ of tomato at 60 and 90 days after transplanting

\begin{tabular}{|c|c|c|c|c|c|c|c|c|}
\hline \multirow[t]{2}{*}{ Treatments } & \multicolumn{2}{|c|}{ Plant height (cm) } & \multicolumn{2}{|c|}{$\begin{array}{l}\text { Number of green } \\
\text { leaves }\end{array}$} & \multicolumn{2}{|l|}{$\begin{array}{l}\text { Leaf } \\
\text { (cm) }\end{array}$} & \multicolumn{2}{|l|}{$\begin{array}{l}\text { Leaf } \\
\text { (cm) }\end{array}$} \\
\hline & $60 \mathrm{DAT}$ & 90 DAT & $\begin{array}{l}60 \\
\text { DAT }\end{array}$ & $\begin{array}{l}90 \\
\text { DAT }\end{array}$ & $\begin{array}{l}60 \\
\text { DAT }\end{array}$ & $\begin{array}{l}90 \\
\text { DAT }\end{array}$ & $\begin{array}{l}60 \\
\text { DAT }\end{array}$ & $\begin{array}{l}90 \\
\text { DAT }\end{array}$ \\
\hline FYM @ 10.0 t ha-1 & 47.82 & 55.49 & 33.59 & 58.09 & 20.69 & 21.19 & 13.49 & 14.59 \\
\hline FYM@ $20.0 \mathrm{tha}^{-1}$ & 52.39 & 58.89 & 35.59 & 64.69 & 21.49 & 22.19 & 14.89 & 15.69 \\
\hline FYM@30.0 tha-1 & 55.49 & 61.99 & 37.49 & 72.49 & 21.99 & 22.99 & 15.79 & 16.49 \\
\hline PM@ 5 t ha ${ }^{-1}$ & 49.39 & 58.39 & 39.29 & 67.99 & 21.19 & 21.59 & 15.19 & 15.59 \\
\hline PM @ $7.5 \mathrm{t} \mathrm{ha}^{-1}$ & 53.99 & 62.49 & 41.69 & 73.69 & 22.19 & 22.69 & 16.39 & 16.89 \\
\hline PM@ 10.0 t ha $^{-1}$ & 56.39 & 64.99 & 42.99 & 77.89 & 22.69 & 23.39 & 16.99 & 17.29 \\
\hline VC @ $2.5 \mathrm{t} \mathrm{ha}^{-1}$ & 44.29 & 52.79 & 31.49 & 54.99 & 20.19 & 20.39 & 12.69 & 14.09 \\
\hline VC @ 5.0 tha $^{-1}$ & 48.39 & 57.69 & 32.99 & 59.69 & 20.89 & 21.19 & 13.49 & 14.99 \\
\hline VCt@ $9.5 \mathrm{tha}^{-1}$ & 50.69 & 62.39 & 34.89 & 64.69 & 21.79 & 22.09 & 14.59 & 15.69 \\
\hline $\begin{array}{l}100 \% \text { RD of NPK } \\
\text { through IF }\end{array}$ & 49.99 & 62.19 & 33.69 & 65.69 & 21.89 & 22.29 & 15.29 & 16.19 \\
\hline SEm \pm & 0.0784 & 0.1523 & 0.1085 & 0.1712 & 0.0693 & 0.0780 & 0.0731 & 0.0843 \\
\hline CD (5\%) & 0.2330 & 0.4527 & 0.3223 & 0.5088 & 0.2058 & 0.2317 & 0.2171 & 0.2504 \\
\hline
\end{tabular}


Table.3 Effect of organic manure on plant height $(\mathrm{cm})$ of tomato at 60 and 90 days after transplanting

\begin{tabular}{|c|c|c|c|c|c|c|}
\hline \multirow[t]{2}{*}{ Treatments } & \multicolumn{2}{|c|}{ Number of nodes } & \multicolumn{2}{|c|}{ Number of branches } & \multicolumn{2}{|c|}{\begin{tabular}{|ll} 
Mean & stem \\
diameter &
\end{tabular}} \\
\hline & $60 \mathrm{DAT}$ & 90 DAT & $60 \mathrm{DAT}$ & 90 DAT & $60 \mathrm{DAT}$ & 90 DAT \\
\hline FYM @ 10.0 t ha & 10.69 & 11.79 & 10.99 & 12.69 & 0.67 & 0.89 \\
\hline FYM @ 20.0 tha ${ }^{-1}$ & 10.99 & 12.09 & 11.69 & 12.99 & 0.75 & 0.94 \\
\hline FYM @ 30.0 tha ${ }^{-1}$ & 11.49 & 12.39 & 12.49 & 13.79 & 0.83 & 1.06 \\
\hline PM @ $0.5 \mathrm{t} \mathrm{ha}^{-1}$ & 10.99 & 12.19 & 11.39 & 13.19 & 0.72 & 0.92 \\
\hline PM @ $7.5 \mathrm{t} \mathrm{ha}^{-1}$ & 11.59 & 12.69 & 12.29 & 13.59 & 0.83 & 1.04 \\
\hline PM@10.0 tha ${ }^{-1}$ & 12.19 & 13.29 & 12.89 & 14.29 & 0.91 & 1.17 \\
\hline VC @ $2.5 \mathrm{tha}^{-1}$ & 10.39 & 11.49 & 10.39 & 12.29 & 0.63 & 0.81 \\
\hline VC @ 5.0 tha $^{-1}$ & 10.89 & 12.09 & 10.89 & 12.79 & 0.71 & 0.93 \\
\hline VCt @ $7.5 t^{-1}$ & 11.39 & 12.59 & 11.59 & 13.39 & 0.77 & 1.02 \\
\hline $\begin{array}{l}100 \% \text { RD of NPK } \\
\text { through IF }\end{array}$ & 11.69 & 12.69 & 11.69 & 13.39 & 0.74 & 1.02 \\
\hline $\operatorname{SEm} \pm$ & 0.0728 & 0.0754 & 0.0902 & 0.0951 & 0.02 & 0.03 \\
\hline $\operatorname{CD}(\overline{5} \%)$ & 0.2163 & 0.2240 & 0.2680 & 0.2826 & 0.07 & 0.10 \\
\hline
\end{tabular}

Table.4 Effect of organic manure on plant height $(\mathrm{cm})$ of tomato at 60 and 90 days after transplanting

\begin{tabular}{|l|l|l|l|l|}
\hline Treatments & $\begin{array}{l}\text { Average fruit } \\
\text { weight g fruit }^{-1}\end{array}$ & $\begin{array}{l}\text { Fruit number } \\
\text { plant }^{-1}\end{array}$ & $\begin{array}{l}\text { Fruit yield } \\
\text { kg plant }^{-1}\end{array}$ & $\begin{array}{l}\text { Fruit yield } \\
\text { (q ha }^{-1} \mathbf{~}\end{array}$ \\
\hline FYM @ 10.0 t ha'
\end{tabular}


Figure.1 Weekly average meteorological parameter prevailed during crop season (2016-17)

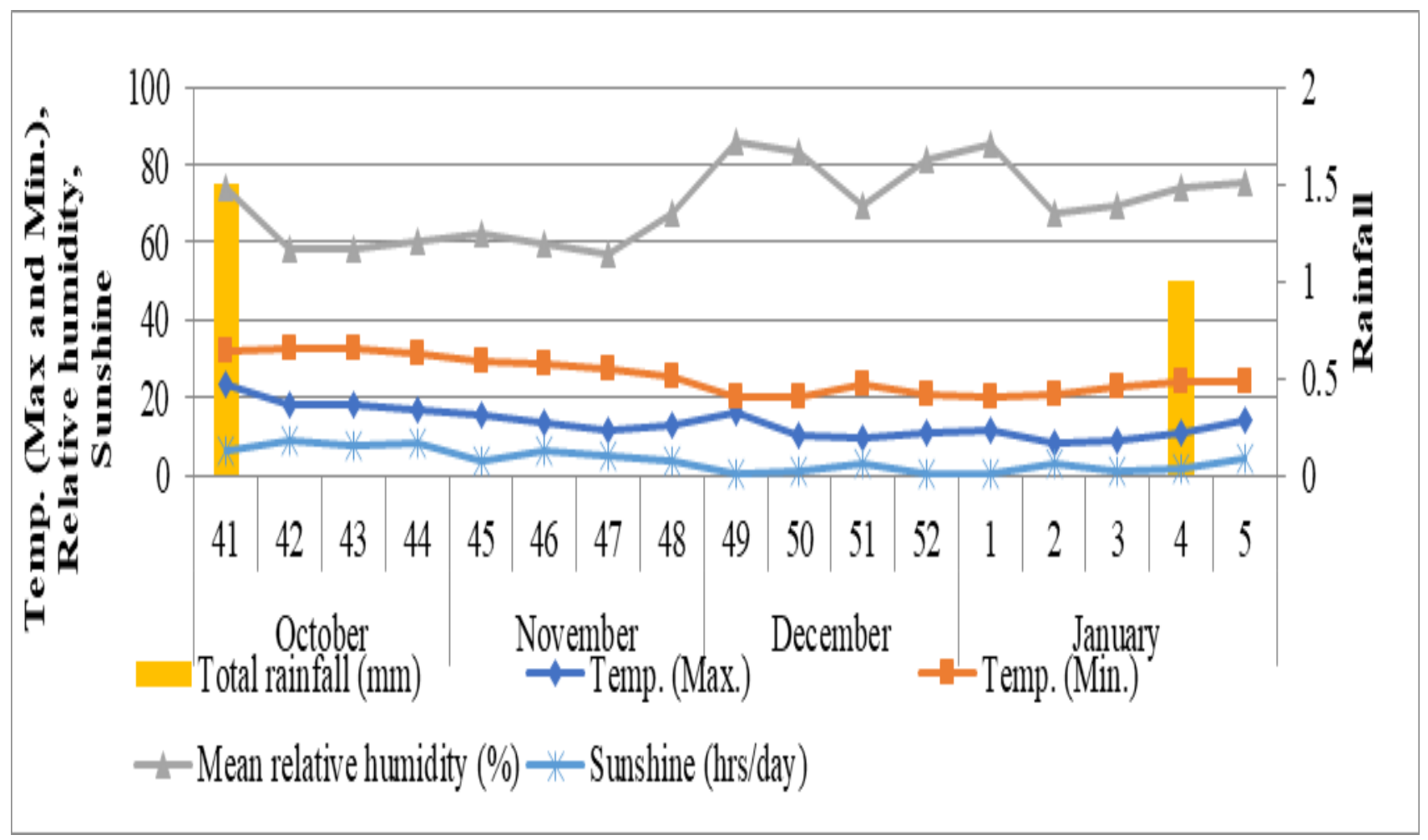

Generally, nitrogen balance is required for the optimum growth and development of vegetable crops, but excess nitrogen causes increase susceptibility of vegetable crops to various diseases and deterioration of keeping quality. The increase in yield with organic manure treatments especially with poultry manure and FYM attributed to overall increase in plant growth characters as discussed. These organic sources besides supplying $\mathrm{N}, \mathrm{P}$ and $\mathrm{K}$ also make unavailable form of nutrients into an available form to facilitate the plants to absorb the nutrients. Application of organic sources encouraged the growth and activity of beneficial microorganisms in the soil and is also helpful in alleviating the increased availability of secondary and micronutrients and is capable of sustaining high crop productivity and soil health also noticed by Yadav et al., (2013). The healthy growth of plants might lead to higher rate of photosynthesis and carbohydrate accumulation observed by
Mohd et al., (2011). resulted into increased size of fruit as well as fruit weight and ultimately overall yield enhancement of tomato. Organically grown foods are perceived as better quality, healthier and more nutritious than conventional counterparts also showed by Warman et al., (1997).

In conclusion, this experiment was laid out with an objective to draw out a productive, and sustainably viable nutrient management practices for tomato production, which is ended with result as application of poultry manure @ $10 \mathrm{t} \mathrm{ha}^{-1}$ is most productive, sustainably viable as, all the growth and yield parameters recoded resounding increment over its own lower levels as well as other organic and inorganic sources. Considering organic verses inorganic sources, results indicate the significant transcendence of organic sources over inorganic nutrient management in tomato crop. 


\section{Acknowledgement}

The author is grateful to her institution where this experiment was carried out and always will be grateful to her supervisor Dr. Diwaker Singh and committee members Dr.Rajeev Singh and Dr. Sunil Kumar Singh, who supports and encouraged her to work hard and as well as provided necessary facilities to carry out this research.

\section{References}

Acharya, S. and Kumar, H. (2018). effect of some organic manure on growth and yield of garlic in greenhouse condition at cold desert high altitude Ladakh region. Defence Life Science Journal, 3(2), 100-104.

Adekiya, A.O., and Agbede, T.M. (2009). Growth and yield of tomato (Lycopersicon esculentum Mill.) as influenced by poultry manure and NPK fertilizer. Emirates Journal of Food and Agriculture, 21(1), 10-20.

Barber, N.J., and Barber, J. (2002). Lycopene and prostate cancer. Prostate Cancer Prostatic Diseases, 5, 6-12.

Bhowmik, D., Sampath Kumar, K.P.S., Paswan, S., and Srivastava, S. (2012). Tomato-A natural medicine and its health benefits. Journal of Pharmacognosy and Phytochemistry, 1 (1), 33-43.

Browaldh, M. (1992). Influence of organic and inorganic fertilizer on common bean (Phaseolus valagnis L.) grown in P-fixing Malic Andosol. Biological Agriculture and Horticulture, 9(8), 4556.

Clinton, S.K. (1998). Lycopene: chemistry, biology and implications for human health and disease. Nutrition Reviews, $56,35-51$.

Geetharani, P. and Parthiban, S. (2014). Effect of organic manures on growth and seed yield of tomato. The Asian Journal of Horticulture, 9(1), 281-282.

Ghosh, P.K., Ramesh, P., Bandyopadhyay, K.K., Tripathi, A.K., Hati, K.M., Misra, A.K. and Acharya, C.L. (2004). Comparative effectiveness of cattle manure, poultry manure, phosphocompost and fertilizer-NPK on three cropping systems in vertisols of semi-arid tropics. I. crop yields and system performance. Bioresource Technology, 95, 77-83.

Kalbani, F.O.S.A., Salem, M.A., Cheruth, A.J., Kurup, S. S., and Kumar, A.S. (2016). Effect of some organic fertilizers on growth, yield and quality of tomato (Solanum lycopersicum). International Letters of Natural Sciences, 53, 1-9.

Kallo, G. (1993). Tomato: in genetic improvement of vegetable crops. Pergamon Press, Oxford England, p. 6.

Kanr, R., Savage, G.P., and Diatta, P.C. (2002). Antioxidants vitamins in four commercially grown tomato cultivars. Nutrition Society of New Zealand, 27, 69-74.

Mahajan, A., Bhagat, R. M., and Gupta, R. D. (2008). Integrated nutrient management in sustainable rice-wheat cropping system for food security in India. SAARC Journal of Agriculture, 6(2), 29-32.

Mohd, T.A., Desai, J.D., Parmar, S.B., and Parmar, B.R. (2011). Effect of organic and inorganic fertilizers on growth, yield and quality of garlic cv GG. -1. The Asian Journal of Horticulture, 6(1), 52-56.

Naidu, A.K., Kushwah, S.S. and Dwivedi, Y.C. (2002). Influence of organic manures, chemical and biofertilizer on growth, yield and economics of brinjal. South Indian Horticulture, 50(7), 370376.

Pandey, S.K., and Chandra, K.K. (2013). 
Impact of integrated nutrient management on tomato yield under farmers field conditions. Journal of Environmental Biology, 34 (6), 10471051

Panse, V.G., and Sukhatme, P.V. 1967. Statistical Methods for Agricultural Workers, 2nd edition, Indian Council of Agricultural Research Publication, New Delhi.

Prasad, R. and Power, J. (1995). Nitrification inhibitors for agriculture, health, and the environment. Advances in Agronomy, $54,233-281$.

Savci, S. (2012). An agricultural pollutant: chemical fertilizer. International Journal of Environmental Science and Development, 3(1), 77-80.

Singh, D.P., Chaubey, T., Singh, B., Mishra U.C. and Chaubey. P.K. (2014). Balance nutrition in tomato through nutrient management for quality production of fruits. Vegetable Science, 41(2), 198-201.

Singh, L., Bhonde, B.R., and Mishra, U.K. (1997). Effect of different organic manures and inorganic fertilizers on yield and quality of Rabi onion. Newsletter NHRDF, 17(3), 1-3.

Sreenivasa, M.N., Nagaraj, M.N., and Bhat, S.N. (2010). Beejamruth: A source for beneficial bacteria. Karnataka Journal of Agricultural Sciences, 17, 72-77.

Sumawat, S., Lakzian, A. and Zmirpour, A. (2001). The effect of Vermicompost on growth characteristics of tomato. Agricultural Sciences and Technology. 15(2): 83-89.

Taiwo, L. B., Adediran, J. A., and Sonubi, O. A. (2007). yield and quality of tomato grown with organic and synthetic fertilizers. International Journal of Vegetable Science, 13(2), 5-19.

Vallejo, F., Barberan T.F.A., and Viguera G.C. (2002). Potential bioactive compounds in health promotion from broccoli cultivars grown in Spain. Journal of the Science of Food and Agriculture, 82, 1293-1297.

Warman, P.R. and Havard, K.A. (1997). Yield, vitamin and mineral contents of organically and conventionally grown carrots and cabbage. Agriculture, Ecosystems and Environment, 61, 15562.

Yadav, S.K., Babu, S., Yadav, M.K., Singh, K., Yadav, G.S., and Pal S. A. (2013). Review of organic farming for sustainable agriculture in northern India. International Journal of Agronomy, 1-8.

\section{How to cite this article:}

Priyanshu Singh, Diwaker Singh, Anand Kumar Singh, B. K. Singh and Tejbal Singh. 2020. Growth and Yield of Tomato Grown Under Organic and Inorganic Nutrient Management. Int.J.Curr.Microbiol.App.Sci. 9(03): 365-375. doi: https://doi.org/10.20546/ijcmas.2020.903.043 